\title{
First description of a deceased juvenile whale shark Rhincodon typus in La Paz Bay, Mexico with comments on morphometry and age estimates
}

\author{
Darren Whitehead ${ }^{1}$, Felipe Galván-Magaña ${ }^{1}$, Katherin Soto-López ${ }^{1}$, Diego Juaristi-Videgaray ${ }^{1}$ \\ Fabián Cervantes-Gutiérrez ${ }^{1}$ \& Edgar Eduardo Becerril-García ${ }^{1,2}$ \\ ${ }^{1}$ Instituto Politécnico Nacional, Centro Interdisciplinario de Ciencias Marinas, La Paz, BCS, México \\ ${ }^{2}$ Pelagios Kakunjá A.C., La Paz, BCS, México \\ Corresponding author: Felipe Galván (galvan.felipe@gmail.com)
}

\begin{abstract}
This paper is the first report with morphometric measurements in the Eastern Tropical Pacific of a deceased $5.48 \mathrm{~m}$ juvenile whale shark Rhincodon typus, from a rare stranding in La Paz Bay in the Gulf of California, Mexico. Biological measurements and age estimation are provided by the analysis of photographs and growth in rings from vertebrae.
\end{abstract}

Keywords: Rhincodon typus; stranding; vertebrae; age; Gulf of California

The whale shark Rhincodon typus (Smith, 1828) represents the monotypic family Rhincodontidae (Compagno et al., 2005). It has a circumglobal distribution, with occurrences reported in all tropical and warm temperate waters, except for the Mediterranean Sea (Compagno et al., 2005). The species habitat can range from an open ocean environment to shallow coastal basins, with a depth distribution from near-surface waters to more than $1,928 \mathrm{~m}$ (Tyminski et al., 2015). It has a yolk sac viviparity mode of reproduction and has been reported to carry as many as 300 pups (Joung et al., 1996). Depending on the location, size at maturity for male sharks ranges between 7-9 $\mathrm{m}$ in total length (TL), while in the female's maturity is estimated to be of $9 \mathrm{~m} \mathrm{TL}$, based on visual and photogrammetry estimates (AcuñaMarrero et al., 2014; Rohner et al., 2015).

In the Gulf of California, whale shark aggregations are known to occur in areas such as Los Ángeles Bay or La Paz Bay, where high zooplankton abundance has been reported (Ketchum et al., 2013). As this species has been observed feeding on prey items such as the euphausiid Nyctiphanes simplex, the copepod Acartia spp., other crustacean's larvae and fish eggs (Ketchum et al., 2013).

The whale shark is an internationally protected species highly susceptible to the fisheries that occurs near coastal aggregation sites (Pierce \& Norman, 2016). Due to the global decline in whale shark populations, the species status was raised to endangered by the International Union for Conservation of Nature and Natural Resources in 2017 (IUCN, 2017). Also, the species is listed on Appendix II of the Convention on International Trade in Endangered Species (CITES), and it is protected by Mexican regulations in the NOM059-SEMARNAT-2010 and NOM-029-PESC-2006 by a national fishery ban for this species. Although the presence of whale sharks in the Gulf of California and the Mexican Caribbean is predictable, there are no published records of stranded whale sharks, age estimations or anatomical observations that can be useful for ecological, phylogenetic or further basic biological studies (Whitehead et al., 2018). The objective of this study was to provide traditional morphometric measurements from a deceased juvenile whale shark in the Gulf of California, through anatomical information, as well as age estimation from the analysis of its vertebrae.

The shark was found deceased in shallow waters off the Ensenada de La Paz, Mexico (249'45"N, $110^{\circ} 24^{\prime} 3^{\prime \prime} \mathrm{W}$ ) on the $16^{\text {th }}$ February 2018 (Fig. 1).

When found, the shark presented seven marks on its head and the anterior part of the pectoral fins, potentially caused by lead fishing sinkers from a net. The probable cause of death was asphyxia provoked by fatigue. However, a more detailed investigation of the species from the necropsy work is currently ongoing, and the cause of death is still not confirmed. The carcass was transported to the Centro Interdisciplinario de Ciencias Marinas (CICIMAR-IPN) by local scientists 


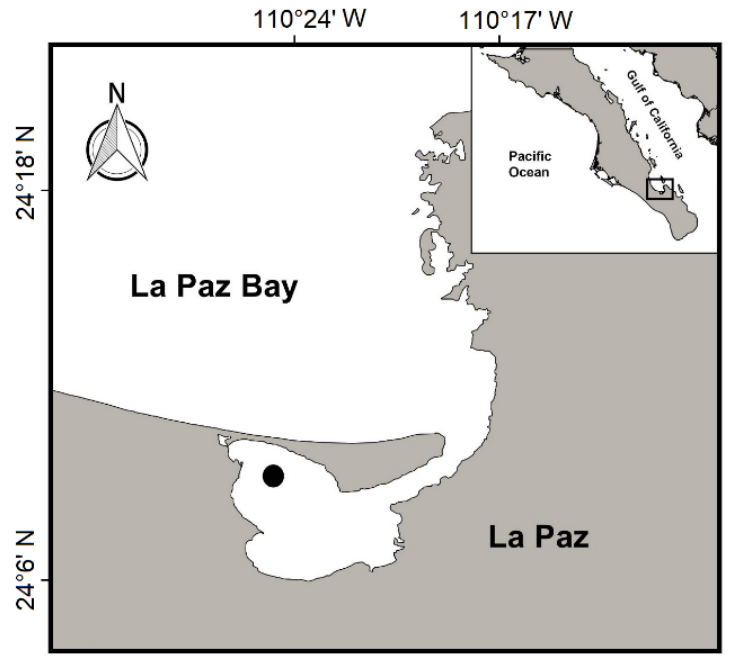

Figure 1. Location of the stranded juvenile whale shark in La Paz Bay, Mexico.

and local environmental authorities to perform a necropsy. On land, pictures were taken, and morphometry was developed before the anatomical analysis of the body (Table 1).

The specimen was identified as Rhincodon typus by its checkerboard pattern of light spots and stripes over a dark body, flattened head with a nearly terminal mouth, and the presence of three prominent ridges along its dorsal flanks (Compagno et al., 2005). Total length (TL) of the shark was $5.48 \mathrm{~m}$, and it was classified as a juvenile male by the presence of slightly calcified claspers with the inability to fully rotate them (Compagno et al., 2005; Acuña-Marrero et al., 2014; Rohner et al., 2015). A bilobed liver was extracted and measured 1.54 and $1.52 \mathrm{~m}$ in TL length for the right and left lobe, respectively. The stomach was emptied and measured $1.15 \mathrm{~m}$ in length and $0.75 \mathrm{~m}$ in width. The spiral valve measured $1.35 \mathrm{~m}$ in length and $0.25 \mathrm{~m}$ in width, with no evidence of the presence of endoparasites in the first section of the intestine. The white muscle was limp and highly greasy, while the red muscle fibers were small and consistent in their density. Dermal hard tissue was discovered in the posterior part of the esophagus (Fig. 2), which may be related to an auxiliary feeding structure to prevent the loss of stomach content.

Vertebrae were extracted from the region under the first dorsal fin, as these vertebrae are acknowledged to be relatively homogeneous and retain the largest radius and clearer growth bands (Campana, 2001). These samples were immediately frozen in the laboratory of CICIMAR-IPN. Before analysis, the vertebrae went through an extensive cleaning with a scalpel and embedded using ethanol (70\%). The vertebrae lateral diameter measured $63.14 \mathrm{~mm}$, dorsal diameter 62.65
Figure 1. Morphometry in $\mathrm{cm}$ and proportion of the whale shark Rhincodon typus specimen stranded in La Paz Bay, Mexico.

\begin{tabular}{|c|c|c|}
\hline Measurements & $\begin{array}{c}\text { Length } \\
(\mathrm{cm})\end{array}$ & $\begin{array}{c}\text { Proportion } \\
(\%)\end{array}$ \\
\hline Total length (TL) & 548.0 & 100.0 \\
\hline Precaudal fin length (PCL) & 439.0 & 80.1 \\
\hline Fork length (FL) & 485.0 & 88.5 \\
\hline Pre-first dorsal fin length (PD1) & 200.0 & 36.5 \\
\hline Pre-second dorsal fin length (PD2) & 366.0 & 66.8 \\
\hline Head length (HDL) & 81.0 & 14.8 \\
\hline Mouth width (MOW) & 103.0 & 18.8 \\
\hline Spiracle length (SPL) & 3.0 & 0.5 \\
\hline Interorbital space (INO) & 80.0 & 14.6 \\
\hline Eye length (EYL) & 3.9 & 0.7 \\
\hline Eye height (EYH) & 4.2 & 0.8 \\
\hline Intergill length (ING) & 44.0 & 8.0 \\
\hline First dorsal-fin length (D1L) & 67.5 & 12.3 \\
\hline First dorsal-fin height (D1H) & 39.3 & 7.2 \\
\hline Second dorsal-fin length (D2L) & 35.0 & 6.4 \\
\hline Second dorsal-fin height $(\mathrm{D} 2 \mathrm{H})$ & 17.0 & 3.1 \\
\hline Pectoral fin base (P1B) & 67.0 & 12.2 \\
\hline Pectoral-fin anterior margin $(\mathrm{P} 1 \mathrm{~A})$ & 95.0 & 17.3 \\
\hline Pelvic-fin length $(\mathrm{P} 2 \mathrm{~L})$ & 32.0 & 5.8 \\
\hline Pelvic-fin height $(\mathrm{P} 2 \mathrm{H})$ & 16.0 & 2.9 \\
\hline Anal-fin length (ANL) & 36.0 & 6.6 \\
\hline Anal-fin height (ANH) & 20.0 & 3.6 \\
\hline Dorsal caudal-fin margin (CDM) & 143.0 & 26.1 \\
\hline Caudal-fin fork length (CFL) & 39.0 & 7.1 \\
\hline Preventral caudal-fin margin (CPV) & 77.0 & 14.1 \\
\hline Clasper inner length (CLI) & 33.0 & 6.0 \\
\hline Clasper outer length (CLO) & 23.0 & 4.2 \\
\hline Trunk width (TRW) & 245.0 & --- \\
\hline Tail width (TAW) & 170.0 & --- \\
\hline Caudal-fin peduncle width (CPW) & 62.5 & --- \\
\hline
\end{tabular}

$\mathrm{mm}$ and height $50.8 \mathrm{~mm}$. The vertebrae were cut both sagittal and transversally, with the use of a transmitted light aided for the counting of the growth bands. A visual count of the growth rings totaled 17 bands with translucent edges (Fig. 3).

Age was estimated by using the total length of the deceased shark (Table 1) and the growth function with the inverse of the model $\mathrm{t}=-\ln \left(\left[1-\left(L_{T} / L_{\infty}\right)\right] / \mathrm{b}\right) / k$ from the two-parameter Von Bertalanffy (1938) growth function, and $\mathrm{b}=\left[\left(L_{\infty}-L_{0}\right) / L_{\infty}\right]$ and $\mathrm{t}=\mathrm{t}_{0}-\ln \left(1-\left[L_{T} /\right.\right.$ $\left.\left.L_{\infty}\right]\right) / k$ for the three-parameter von Bertalanffy models. Where $k$ is the growth constant, $t_{0}$ is the age at length zero, $L_{T}$ is the total length recorded in this study, $L_{\infty}$ is the asymptotic total length and $L_{0}$ is the size at birth which is expected to be $0.64 \mathrm{~m}$ adopted from the largest full-term embryo data of Joung et al. (1996). Using previous von Bertalanffy growth models for whale sharks by Wintner (2000) and Hsu et al. (2014), it was possible to estimate that the shark was 18-19 years old, adopting the criteria of the formation of a single annual 

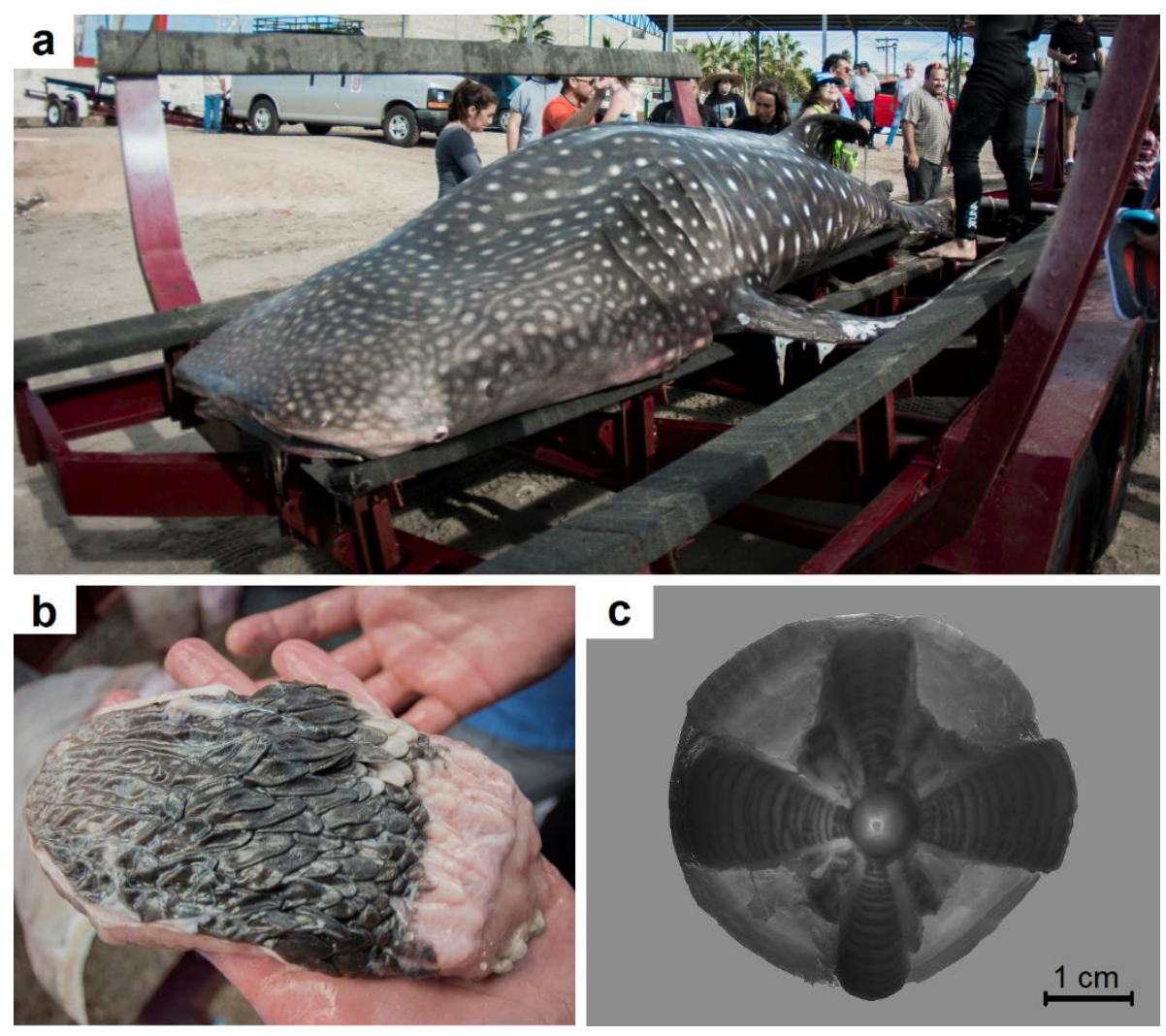

Figure 2. a) Reported whale shark from the stranding in La Paz Bay, Mexico, b) detail of the anterior part of the esophagus, c) sagittal cut of the vertebrae.

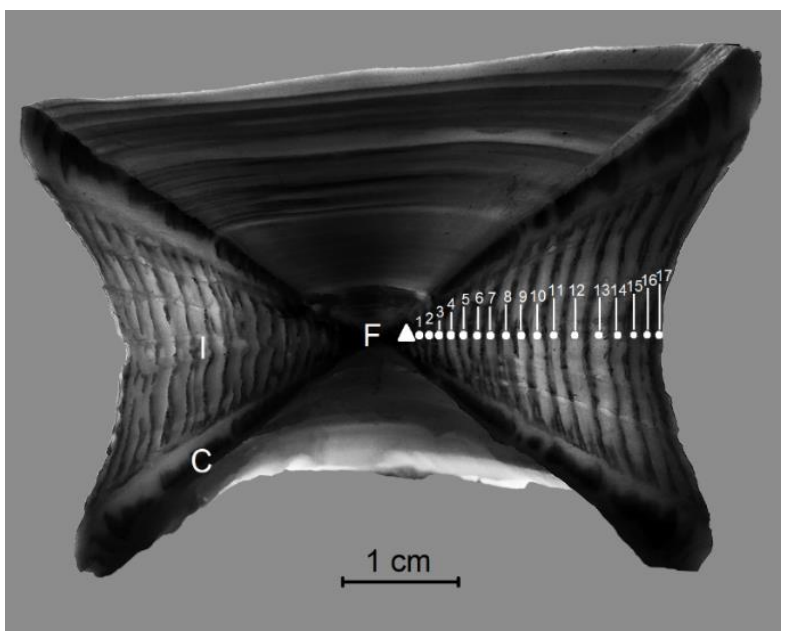

Figure 3. Longitudinal cut of the whale shark vertebrae reported in this study, with the focus (F); birthmark ( $\mathbf{\Delta})$; Corpus calcareum (C); Intermedialia (I); and 17 growth rings $(\bullet)$.

band per year. However, the age of the shark was assessed to be 17 years old by the visual observations of the vertebrae growth rings (Table 2).
Records of whale shark strandings have been reported in other countries such as South Africa, India, Australia and Mozambique (Kakini et al., 1959; Beckley et al., 1997; Speed et al., 2009; Rohner et al., 2013). These studies have been useful in terms of fatty acids, stomach contents, and biogeography, however, detailed morphometric data is usually not provided. The presented results in this study are consistent with the information reported by Hsu et al. (2014) from juvenile whale sharks of the north-western Pacific. However, the use of further detailed morphometry and age estimations of mature whale sharks could complement the information regarding morphometry, basic biology and demography of each population. Additionally, the obtention of morphometric data from stranded animals with the application of photogrammetry techniques during the monitoring of living sharks is suggested, as this could generate accurate information for the assessment of growth and maturity length, phylogenetics and potential anatomical changes during the life cycle of $R$. typus (Rohner et al., 2011, 2015; Jeffreys et al., 2012; Whitehead et al., 2018). 
Table 2. Estimation of the reported whale shark using the model parameters of two and three-parameters with von Bertalanffy (1938). $k$ : growth constant, $L \infty$ : asymptotic total length, $t 0$ : age at length zero.

\begin{tabular}{lccc}
\hline Parameter & $\begin{array}{c}\text { Wintner (2000) } \\
\text { (annual band) }\end{array}$ & $\begin{array}{c}\text { Hsu } \text { et al. }(2014) \\
\text { (annual band) }\end{array}$ & $\begin{array}{c}\text { Hsu } \text { et al. }(2014) \\
\text { (biannual band) }\end{array}$ \\
\hline$k$ & 0.032 & 0.021 & 0.037 \\
$L_{\infty}(\mathrm{m})$ & 11.79 & 15.34 & 16.8 \\
$t_{0}$ & -0.85 & --- & --- \\
Estimated age (years) & 18.68 & 19.01 & 9.62 \\
\hline
\end{tabular}

\section{ACKNOWLEDGMENTS}

We thank the Procuraduría Federal de Protección al Ambiente, Museo de la Ballena y Ciencias del Mar, MMARES A.C./Red de Varamientos de La Paz, Roberto Robles, C. Ballinez-Ambriz and C. LópezGarcía for all their support. We also thank two anonymous reviewers for the improvement of our manuscript, D. Bernot-Simon for the English review, the Instituto Politécnico Nacional for funding through grants from the COFAA (Comisión de Operación y Fomento de Actividades Académicas), the EDI (Estímulo al Desempeño de los Investigadores) and CONACyT for the provided scholarships. This study was conducted under the permit SGPA/DGVS 05605/17 provided by the Dirección General de Vida Silvestre from the Subsecretaría de Gestión para la Protección Ambiental of SEMARNAT.

\section{REFERENCES}

Acuña-Marrero, D., Jiménez, J., Smith, F., Doherty, P.F., Hearn, A., Green, J.R., Paredes-Jarrín, J. \& Salinas-deLeón, P. 2014. Whale shark (Rhincodon typus) seasonal presence, residence time and habitat use at Darwin Island, Galapagos Marine Reserve. Plos One, 9(12): e115946. doi: 10.1371/journal.pone.0115946.

Beckley, L.E., Cliff, G., Smale, M.J. \& Compagno, L.J.V. 1997. Recent strandings and sightings of whale sharks in South Africa. Environmental Biology of Fishes, 50(3): 343-348.

Campana, S.E. 2001. Accuracy, precision and quality control in age determination, including a review of the use and abuse of age validation methods. Journal of Fish Biology, 59(2): 197-242.

Compagno, L.J.V., Dando, M. \& Fowler, S. 2005. Sharks of the world. Princeton University Press, New Jersey.

Hsu, H.H., Joung, S.J., Hueter, R.E. \& Liu, K.M. 2014. Age and growth of the whale shark (Rhincodon typus) in the north-western Pacific. Marine and Freshwater Research, 65(12): 1145-1154.
International Union for Conservation of Nature (IUCN). 2017. IUCN report for the World Heritage Committee, 41th session, Warsaw, Poland.

Jeffreys, G.L., Rowat, D., Marshall, H. \& Brooks, K. 2012. The development of robust morphometric indices from accurate and precise measurements of free-swimming whale sharks using laser photogrammetry. Journal of the Marine Biological Association of the United Kingdom, 93: 309-320. doi: 10.1017/ S0025315412001312.

Joung, S.J., Chen, C.T., Clark, E., Uchida, S. \& Huang, W.Y. 1996. The whale shark, Rhincodon typus, is a livebearer: 300 embryos found in 'megamamma' supreme. Environmental Biology of Fishes, 46(3): 219-223. doi: 10.1007/BF00004997.

Kaikini, A.S., Rao, V. \& Dhulkhed, M.H. 1959. A note on the whale shark Rhincodon typus Smith, stranded off Mangalore. Journal of the Marine Biological Association of India, 1(1): 92-93.

Ketchum, J.T., Galván-Magaña, F. \& Klimley, P.A. 2013. Segregation and foraging ecology of whale sharks, Rhincodon typus, in the southwestern Gulf of California. Environmental Biology of Fishes, 96: 779795. doi: 10.1007/s10641-012-0071.

Pierce, S.J. \& Norman, B. 2016. Rhincodon typus. The IUCN Red List of Threatened Species 2016, [http://dx.doi.org/10.2305/IUCN.UK.2016-1.RLTS.T 19488A2365291.en]. Reviewed: 5 April 2018.

Rohner, C.A., Richardson, A.J., Marshall, A.D., Weeks, S.J. \& Pierce, S.J. 2011. How large is the world's largest fish? Measuring whale sharks Rhincodon typus with laser photogrammetry. Journal of Fish Biology, 78(1): 378-385.

Rohner, C.A., Couturier, L.I., Richardson, A.J., Pierce, S.J., Prebble, C.E., Gibbons, M.J. \& Nichols, P.D. 2013. Diet of whale sharks Rhincodon typus inferred from stomach content and signature fatty acid analyses. Marine Ecology Progress Series, 493: 219235.

Rohner, C.A., Richardson, A.J., Prebble, C.E., Marshall, A.D., Bennett, M.B., Weeks, S.J., Cliff, G., Wintner, S.P. \& Pierce, S.J. 2015. Laser photogrammetry 
improves size and demographic estimates for whale sharks. PeerJ, 3: e886. doi: 10.7717/peerj.886

Speed, C.W., Meekan, M.G., Russell, B.C. \& Bradshaw, A.J.A. 2009. Recent whale shark (Rhincodon typus) beach strandings in Australia. Marine Biodiversity Records, 2: e15.

Tyminski, J.P., De la Parra-Venegas, R., Cano, J.G. \& Hueter, R.E. 2015. Vertical movements and patterns in the diving behavior of whale sharks as revealed by pop-up satellite tags in the eastern Gulf of Mexico. Plos One, 10(11): e0142156. doi: 10.1371/journal. pone. 0142156 .

Von Bertalanffy, L. 1938. A quantitative theory of organic growth (inquiries on growth laws II). Human Biology, 10: 181-213.

Received: 12 April 2018; Accepted: 26 March 2019
Whitehead, D.A., Becerril-García, E.E., Petatán-Ramírez, D., Vázquez-Haikin, A., González-Armas, R. \& Galván-Magaña, F. 2018. Whale shark Rhincodon typus strandings in the Gulf of California, Mexico. Journal of Fish Biology, 94(1): 165-167. doi: 10.1111/ jfb. 13845 .

Wintner, S.P. 2000. A preliminary study of vertebral growth rings in the whale shark, Rhincodon typus, from the east coast of South Africa. Environmental Biology of Fishes, 59: 441-451. doi: 10.1023/A: 1026564707027. 